\title{
Ellipsis
}

Volume 43

Article 10

2016

\section{The Eschatologist's Wife}

Jade Hurter

University of New Orleans

Follow this and additional works at: https://scholarworks.uno.edu/ellipsis

\section{Recommended Citation}

Hurter, Jade (2016) "The Eschatologist's Wife," Ellipsis: Vol. 43 , Article 10.

DOI: https://doi.org/10.46428/ejail.43.10

Available at: https://scholarworks.uno.edu/ellipsis/vol43/iss1/10

This Poetry is brought to you for free and open access by the Department of English and Foreign Languages at ScholarWorks@UNO. It has been accepted for inclusion in Ellipsis by an authorized editor of ScholarWorks@UNO.

For more information, please contact scholarworks@uno.edu. 


\title{
The Eschatologist's Wife
}

\author{
Jade Hurter \\ Andrea Saunders Gereighty / Academy of American Poets Award Second Place Winner
}

I.

I was a child when we married, nineteen, with seasalt under my nails. It was February, beneath a dying oak. When he kissed me, there was a pearl hidden on his tongue. I took it into my mouth carefully so as not to choke.

II.

Our marriage bed filled with the feathers

of crows. Their ghosts invaded my sleep.

Mornings I would find eyelashes in the strangest places, behind my ears and between pages

of the Sunday Times

or embedded in egg whites, partly cooked.

III.

In the top drawer of his bureau: three chunks of chalcedony and a nest of my own dark hair, his talismans against mortality.

Those days were a haze of lilac and I was out on the porch every night, smearing fireflies into my skin.

IV.

For three years he covered the bedroom walls with clocks, loud as click beetles.

Still he slept, lashes dark and lips parted.

Mornings we memorized the Harper's index and ate real maple syrup, the consistency of water. 
V.

One summer we awoke to find the yard

a jungle of poison hemlock, sprung up overnight, choking the fruits off of the peach tree.

He uprooted the plants with bare palms.

For weeks after he wore gardening gloves

when we made love.

VI.

That year we vacationed on a shoreline covered in pink jellyfish. I gathered them in piles

on the sand. They glowed in the sunlight.

Dead starfish dried in the sun

as we cooled our hands in the tidepools.

VII.

He became an old man

as my hair silvered.

I watched him on the porch after dusk

rubbing asteroid dust over his body.

Those nights the earth became small

and the flowers waned dark.

VIII.

He left gemstones

scattered throughout the house.

I buried him in the sea,

his ashes floating like wet stars.

Alone, now, I think of the seaweed

drinking him in like salt. 